\title{
RESENTRALISASI DALAM PEMBAGIAN KEWENANGAN PEMANFAATAN ENERGI PANAS BUMI
}

\author{
Canggih Prabowo \\ email: canggihprabowo@gmail.com
}

\begin{abstract}
The promulgation of Law no. 23 of 2014 re. Local Government, strengthening local government's authority, is expected to provide a way out to the problem of how to harvest geothermal energy found in forest protected areas (within the jurisdiction of local government) to supply the increasing demand for electricity throughout Indonesia. For more than 10 years after the promulgation of Law no. 32 of 2004, the central government program to accelerate the utilization of geothermal energy source found within protected forest zones had come to a full stop. This article discusses the issue of how government authority (central-local) related to the above problem had been distributed and the existing tension between central-local government. The central government tendency to take back authorities previously granted to local authorities defies the whole effort at making government more accountable, efficient and prevention of externalities.
\end{abstract}

Keywords:

recentralization. full autonomy. distribution of authorities.

\begin{abstract}
Abstrak
Penerbitan Undang-Undang No. 23 Tahun 2014 tentang Pemerintah Daerah diharapkan dapat menjawab persoalan penyediaan pasokan ketenagalistrikan di daerah melalui pemanfaatan energi panas bumi. Ini menjadi penting karena selama lebih dari sepuluh tahun sejak berlakunya UndangUndang No. 32 Tahun 2004, program percepatan pembangunan pembangkit listrik panas bumi dalam kawasan hutan terhenti. Tulisan ini hendak menelaah persoalan penyelenggaraan otonomi daerah di bidang penyediaan tenaga listrik serta tarik menarik kewenangan di bidang tersebut antara pemerintah pusat dengan pemerintah daerah yang ditunjukkan dengan adanya resentralisasi kewenangan. Dipertaruhkan di sini adalah penyelenggaraan pemerintahan di tingkat lokal maupun pusat yang semestinya dilandaskan prinsip akuntabilitas, efisiensi dan penghindaran ekstenalitas.
\end{abstract}

Kata Kunci:

resentralisasi. otonomi seluas-luasnya. pembagian kewenangan.

\section{Pengantar}

Pada tahun 2006, hampir di semua wilayah pelosok desa di Pulau Jawa mengalami krisis pasokan ketenagalistrikan hingga terjadi pemadaman bergilir diantaranya di Aceh-Sumatera Utara, Sumatera Barat, Kepulauan Riau, Bangka, Sumatera Bagian Selatan, Kalimantan Barat, Kalimantan Timur, Kalimantan Utara, Kalimantan Selatan, Kalimantan Tengah, Sulawesi Utara-Gorontalo serta Papua. 
Daerah-daerah tersebut dikategorikan sebagai daerah krisis yang kekurangan pasokan listrik dengan beban puncak kurang dari 10 Megawatt (MWe). ${ }^{1}$

Kondisi di atas terjadi dikarenakan pertumbuhan ekonomi berbanding lurus dengan pertumbuhan konsumsi listrik dan pada saat yang bersamaan tidak diimbangi penyediaan atau pasokan energi listrik. Menurut hasil studi Perusahaan Listrik Negara (Persero), Pulau Jawa diperkirakan akan mengalami krisis listrik pada tahun 2018 akibat pertumbuhan beban listrik yang terus meningkat dengan pertumbuhan per tahun yang mencapai sekitar 8-9\% per tahun ${ }^{2}$, di samping itu masih terdapat 2.519 desa yang belum memperoleh jaringan listrik di Indonesia. ${ }^{3}$

Untuk mengatasi hal tersebut, di tahun 2006 Presiden Susilo Bambang Yudhoyono menerbitkan program percepatan pembangunan pembangkit listrik 10.000 MWe tahap pertama untuk mempersiapkan ketersediaan energi nasional di masa depan mengimbangi peningkatan kebutuhan pertumbuhan beban listrik berdasarkan Peraturan Presiden No. 71 Tahun 2006 sebagaimana telah diubah beberapa kali terakhir dengan Peraturan Presiden No. 45 Tahun 2014 tentang perubahan ketiga atas Peraturan Presiden No. 71 Tahun 2006 tentang Penugasan Kepada PT Perusahaan Listrik Negara (Persero) Untuk Melakukan Percepatan Pembangunan Pembangkit Tenaga Listrik Yang Menggunakan Batubara.

Pilihan penggunaan jenis pembangkit listrik ini dijalankan agar adanya efisiensi biaya untuk menggantikan pembangkit listrik bertenaga minyak bumi atau solar sehingga dapat meningkatkan jumlah pasokan listrik dengan harga yang lebih terjangkau. Namun, hal tersebut kurang memberikan nilai tambah bagi lingkungan hidup lokal dan global disebabkan menghasilkan polutan C02, SO2,

\footnotetext{
1 Tanpa Nama, Tanpa Pertumbuhan Pembangkit, 2018 Pulau Jawa Krisis Listrik, http://www.esdm.go.id/berita/39-listrik/6745-tanpa-pertumbuhan-pembangkit-2018-pulaujawa-krisis-listrik.html, di akses 26 Maret 2015.

2 Pusat Data dan Informasi Energi dan Sumber Daya Mineral Kementerian Energi dan Sumber Daya Mineral, Kajian Isu-Isu Sektor Laporan Akhir Analisis Isu-Isu Sektor Energi dan Sumber Daya Mineral, 2012, hlm. 4.

3 Tanpa Nama, Pemerintah Dorong Swasta Kembangkan Listrik Perdesaan, http://www.djk.esdm.go.id/index.php/detail-berita?ide=4210, di akses 26 Maret 2015.
} 
NO2, dan CxHy dimana saat ini lebih dari 80\% listrik bersumber dari bahan bakar fosil sehingga hal itu menciptakan ketergantungan pada bahan bakar fosil.

Dikarenakan kondisi tersebut, pada tahun 2010 pemerintah meluncurkan proyek listrik 10.000 Mwe tahap kedua berdasarkan Peraturan Presiden Nomor 4 Tahun 2010 sebagaimana diubah melalui Peraturan Presiden Nomor 194 Tahun 2014 tentang Perubahan Kedua Penugasan Kepada PT Perusahaan Listrik Negara (Persero) Untuk Melakukan Percepatan Pembangunan Pembangkit Tenaga Listrik Yang Menggunakan Energi Terbarukan, Batu Bara dan Sumber Daya Mineral.

Hal itu kemudian ditindaklanjuti dengan Peraturan Menteri Energi Sumber Daya Mineral No. 01 Tahun 2012 sebagaimana telah diubah beberapa kali terakhir dengan Peraturan Menteri Energi Sumber Daya Mineral No. 32 Tahun 2014 tentang Perubahan Ketiga Atas Peraturan Menteri Energi dan Sumber Daya Mineral No. 15 Tahun 2010 Tentang Daftar Proyek-Proyek Percepatan Pembangunan Pembangkit Tenaga Listrik Yang Menggunakan Energi Terbarukan, Batubara dan Gas Serta Transmisi Terkait.

Program percepatan pembangkit listrik tahap pertama di atas, pada tahun 2011 mulai terlihat hasilnya dengan makin berkurangnya frekwensi pemadaman terutama di Pulau Jawa ${ }^{4}$ sejalan dengan penerimaan negara bukan pajak dari penggunaan kawasan hutan pada tahun 2011 hingga tahun 2014 mencapai Rp 1 triliun per tahunnya sedangkan potensi batubara diperkirakan mencapai 93,4 miliar ton berada di kawasan hutan Sumatera bagian Selatan, Jawa Tengah, Kalimantan Timur, Kalimantan Tengah, Sulawesai Tengah, Sulawesi Utara, Papua dan Papua Barat. ${ }^{5}$

\footnotetext{
4 Tanpa Nama, Industri Kelistrikan Indonesia, http://www.datacon.co.id/Listrik2011Industri.html, di akses 26 Maret 2015.

5 Gustidha Budiartie, Pendapatan Dari Hutan Ditargetkan Naik Pada 2011, https://m.tempo.co/read/news/2010/12/23/090301127/pendapatan-dari-hutan-ditargetkannaik-pada-2011, di akses 26 Maret 2015.
} 


\section{Gejala Resentralisasi Urusan dan Kewenangan Lintas Sektor Sumber Daya}

Capaian hasil yang diuraikan di atas belum diiringi dengan penyelesaian 12 proyek panas bumi yang ada dalam kondisi mangkrak di mana sebagian besar berlokasi di Pulau Jawa, salah satunya terletak di Gunung Ciremai di Jawa Barat pada tahun 2011 yang ditetapkan sebagai Wilayah Kerja Pertambangan Panas Bumi (WKP Panas Bumi) Daerah Gunung Cermai melalui Keputusan Menteri Energi dan Sumber Daya Alam (ESDM) No. 1153K/30/MEM/2011. WKP mencakup wilayah Kabupaten Kuningan dan Majalengka dengan luasnya mencapai 24.330 hektar6. Tidak selesainya proyeknya tersebut terkendala permasalahan di antaranya:

1. Penolakan masyarakat di Kampung Wage, Kelurahan Cigugur, Kecamatan Cigugur yang telah lama menempati daerah sekitar dan dalam hutan Gunung Ciremai salah satunya di Dusun atau Kampung Palutungan, Desa Cisantana, Kecamatan Cigugur. Masyarakat menolak dikarenakan proyek diduga akan merusak 300 situs-situs budaya Sunda lama dengan periodisasi situs sejak zaman Pre Historic-Neolithicum (1500 thn sebelum masehi)-periode CiwaBudha hingga periode Syiar Islam. ${ }^{7}$

2. Besaran nilai pengembangan panas bumi 110 Mwe dan cadangan nilai panas bumi 150 Mwe tidak ekonomis untuk dikembangkan berdasarkan Peraturan Menteri Energi dan Sumber Daya Mineral No. 01 Tahun 2012 sebagaimana telah diubah dengan Peraturan Menteri Energi dan Sumber Daya Mineral No. 21 Tahun 2013 tentang Perubahan atas Peraturan Menteri Energi dan Sumber Daya Mineral Nomor 15 Tahun 2010 tentang Daftar-Daftar ProyekProyek Percepatan Pembangunan Pembangkit Listrik Tenaga Listrik Yang Menggunakan Energi Terbarukan, Batubara dan Gas Serta Transmisi Terkait.

Terkait kondisi sosial dan nilai keekonomian tersebut, pemerintah memberikan tenggat waktu menyelesaikan sampai dengan 31 Desember 2014,

\footnotetext{
6 Administrator, Kronologis Perkembangan Wilayah Kerja Panas Bumi Gunung Ciremai, http://www.esdm.go.id/berita/323-energi-baru-dan-terbarukan/6747-kronologisperkembangan-wilayah-kerja-panas-bumi-gunung-ciremai.html, di akses 26 Maret 2015.

7 Siaran Pers Gerakan Massa Pejuang Untuk Rakyat, 07 Mei 2014.
} 
apabila belum diselesaikan akan diserahkan kembali kepada Pemerintah Daerah Provinsi dan Pemerintah Daerah Kabupaten/Kota yang memberikan izin ${ }^{8}$ berdasarkan Peraturan Pemerintah No. 70 Tahun 2010 tentang Perubahan Atas Peraturan Pemerintah No. 59 Tahun 2007 tentang Kegiatan Panas Bumi, disamping itu materi muatan dalam Undang-Undang No. 23 Tahun 2003 tentang Panas Bumi turut memberikan pengaruh atas kendala tersebut selanjutnya dijelaskan dalam tabel di bawah ini:

\begin{tabular}{|c|c|c|c|c|}
\hline $\begin{array}{l}\begin{array}{l}\text { Kategori } \\
\text { Usaha Jenis } \\
\text { perizinan }\end{array} \\
\text { Pertambangan }\end{array}$ & $\begin{array}{l}\text { Penguasaan } \\
\text { dan } \\
\text { penggunaan } \\
\text { kawasan Hutan }\end{array}$ & \multicolumn{3}{|c|}{$\begin{array}{l}\text { Pembagian kewenangan antara Pemerintah Pusat, } \\
\text { Pemerintahan Propinsi dan Pemerintahan Kabupaten/Kota }\end{array}$} \\
\hline $\begin{array}{l}\text { Izin usaha } \\
\text { pertambangan }\end{array}$ & $\begin{array}{l}\text { Kawasan Hutan } \\
\text { produksi dan } \\
\text { hutan lindung } \\
\text { melalui skema } \\
\text { Izin Pinjam } \\
\text { Pakai Kawasan } \\
\text { Hutan } \\
\text { diterbitkan oleh } \\
\text { Menteri } \\
\text { Kehutanan }\end{array}$ & $\begin{array}{l}\text { Pemerintah Pusat, } \\
\text { Pemerintah } \\
\text { Propinsi dan } \\
\text { Pemerintah } \\
\text { Kabupaten/Kota } \\
\text { melakukan survei } \\
\text { Pendahuluan dan } \\
\text { melakukan } \\
\text { pelelangan WKP } \\
\text { Panas Bumi. }\end{array}$ & $\begin{array}{l}\text { Penetapan WKP Panas } \\
\text { Bumi berada di lintas } \\
\text { Provinsi menjadi } \\
\text { kewenangan } \\
\text { Pemerintah Pusat } \\
\text { Penetapan WKP Panas } \\
\text { Bumi berada lintas } \\
\text { kabupaten/kota } \\
\text { menjadi kewenangan } \\
\text { Gubernur. } \\
\text { Penetapan WKP Panas } \\
\text { Bumi berada di } \\
\text { Kabupaten/Kota } \\
\text { menjadi kewenangan } \\
\text { Pemerintah } \\
\text { Kabupaten/Walikota. }\end{array}$ & $\begin{array}{l}\text { Pemerintahan } \\
\text { Daerah Propinsi } \\
\text { dan } \\
\text { Pemerintahan } \\
\text { Daerah } \\
\text { Kabupaten/Kota } \\
\text { berwenang } \\
\text { menerbitkan Izin } \\
\text { Pemanfaatan } \\
\text { Langsung Non } \\
\text { Listrik dan } \\
\text { Pemanfaatan } \\
\text { Tidak Langsung } \\
\text { untuk } \\
\text { pembangkit } \\
\text { tenaga listrik. }\end{array}$ \\
\hline \multicolumn{5}{|c|}{$\begin{array}{l}\text { BAB VII } \\
\text { PENGGUNAAN LAHAN } \\
\text { Pasal } 16 \\
\text { (3) Kegiatan Usaha Pertambangan Panas Bumi tidak dapat dilaksanakan di : } \\
\text { a. tempat pemakaman, tempat yang dianggap suci, tempat umum, sarana dan prasarana umum, } \\
\text { cagar alam, cagar budaya, serta tanah milik masyarakat adat; } \\
\text { b. lapangan dan bangunan pertahanan negara serta tanah di sekitarnya; } \\
\text { c. bangunan bersejarah dan simbol-simbol negara; } \\
\text { d. bangunan, rumah tinggal, atau pabrik beserta tanah pekarangan sekitarnya; } \\
\text { e. tempat lain yang dilarang untuk melakukan kegiatan usaha sesuai dengan ketentuan peraturan } \\
\text { perundang-undangan yang berlaku. }\end{array}$} \\
\hline
\end{tabular}

Tabel 1: Undang-Undang 32 Tahun 2004 tentang Pemerintahan Daerah

Ketiga permasalahan dalam tabel di atas diatasi dengan Nota Kesepahaman Antara Kementerian Energi dan Sumber Daya Alam Mineral dengan Kementerian

8 Sucipto, Pemerintah Ultimatum 12 Proyek Panas Bumi Mangkrak, http://m.wartaekonomi.co.id/berita10221/pemerintah-ultimatum-12-proyek-panas-bumimangkrak.html, di akses 26 Maret 2015. 
Kehutanan No. 7662/05/MEM.S/2001 dan No. NK.16/Menhut-II/201. Nota Kesepahaman Antara Kementerian Energi dan Sumber Daya Alam Mineral dengan Kementerian Kehutanan No. 7662/05/MEM.S/2001 dan Nomor NK.16/MenhutII/201 memuat beberapa WKP Panas Bumi di Jawa Barat diantaranya:

\begin{tabular}{|c|c|c|c|c|}
\hline No & $\begin{array}{l}\text { Pembangkit Listrik } \\
\text { Tenaga Panas } \\
\text { Bumi (PLTP) }\end{array}$ & $\begin{array}{l}\text { Wilayah Kerja Panas } \\
\text { Bumi }\end{array}$ & Kategori Hutan & $\begin{array}{l}\text { Estimasi } \\
\text { Kapasitas } \\
\text { (MW) }\end{array}$ \\
\hline 1 & $\begin{array}{l}\text { PLTP Karaha } \\
\text { Bodas }\end{array}$ & $\begin{array}{l}\text { Kabupaten Tasikmalaya } \\
\text { dan Kabupaten Garut, }\end{array}$ & Kawasan Hutan Lindung & $140 \mathrm{MW}$ \\
\hline 2 & $\begin{array}{l}\text { PLTP Gunung } \\
\text { Tampomas } \\
\end{array}$ & $\begin{array}{l}\text { Kabupaten Sumedang dan } \\
\text { Kabupaten Subang }\end{array}$ & Kawasan Hutan Lindung & $45 \mathrm{MW}$ \\
\hline 3 & $\begin{array}{l}\text { PLTP Gunung } \\
\text { Tangkuban Perahu }\end{array}$ & $\begin{array}{l}\text { Kabupaten Subang, } \\
\text { Kabupaten Bandung, dan } \\
\text { Kabupaten Purwakarta }\end{array}$ & $\begin{array}{l}\text { Kawasan Hutan Lindung dan } \\
\text { Hutan Produksi }\end{array}$ & $170 \mathrm{MW}$ \\
\hline 4 & $\begin{array}{l}\text { PLTP Cisolok } \\
\text { Cisukarame }\end{array}$ & Kabupaten Sukabumi & $\begin{array}{l}\text { Kawasan Hutan Konservasi } \\
\text { dalam Taman Nasional Gunung } \\
\text { Salak }\end{array}$ & $160 \mathrm{MW}$ \\
\hline
\end{tabular}

Tabel 2: Wilayah Kerja Pertambangan Panas Bumi di Jawa Barat

Terbitnya nota kesepahaman ini bertujuan untuk mempercepat proses perizinan bertahap yang perlu dikeluarkan oleh Kementerian Energi Sumber Daya dan Mineral, Kementerian Kehutanan, maupun Pemerintah Daerah Provinsi dan Pemerintah Kabupaten/Kota pada wilayah administrasi Pemerintahan Daerah pada pengusahaan panas bumi di kawasan hutan produksi dan hutan lindung serta mempersiapkan langkah-langkah agar kegiatan pemanfaatan panas bumi dapat dilakukan di kawasan hutan konservasi dengan tetap mempertimbangkan prinsip-prinsip konsevasi termuat dalam Pasal 1.

Walau demikian nota kesepahaman tersebut dalam praktik hukum tidak dapat dianggap sebagai perjanjian berdasarkan Pasal 1320 dan Pasal 1338 Kitab Undang-Undang Hukum Perdata. Dalam praktik hal ini memberi kesan memperluas penguasaan jenis usaha panas bumi yang dikategorikan sebagai pertambangan yang dapat dilakukan pada lahan kawasan hutan produksi, kawasan hutan lindung dan kawasan hutan konservasi yang terdiri dari: 


\begin{tabular}{|c|c|c|c|}
\hline Kewenangan & \multicolumn{2}{|c|}{ Kawasan Hutan Konservasi } & Kewenangan \\
\hline & $\begin{array}{l}\text { Kawasan Suaka Alam } \\
\text { (KSA) }\end{array}$ & 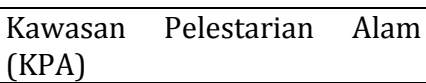 & \\
\hline $\begin{array}{l}\text { Pemerintah Provinsi } \\
\text { atau Pemerintah } \\
\text { Kabupaten/Kota }\end{array}$ & $\begin{array}{lr}\text { Cagar } & \text { Alam (CA) dan } \\
\text { Suaka } & \text { Margasatwa } \\
(\mathrm{SM}) & \\
\end{array}$ & $\begin{array}{l}\text { Taman Nasional (TN), Taman } \\
\text { Wisata Alam (TWA), dan } \\
\text { Taman Hutan Raya (TAHURA). }\end{array}$ & $\begin{array}{l}\text { Pemerintah } \\
\text { Pusat }\end{array}$ \\
\hline
\end{tabular}

Tabel 2: Kawasan Hutan Konservasi

Sedangkan materi muatan nota kesepahaman tersebut dibatasi berdasarkan Pasal 38 ayat (1) Undang-Undang No. 41 Tahun 1999 sebagaimana telah diubah dengan Undang-Undang No. 19 Tahun 2004 tentang Kehutanan (UU Kehutanan) bahwa "Penggunaaan kawasan hutan untuk kepentingan pembangunan di luar kegiatan kehutanan hanya dapat dilakukan di dalam kawasan hutan produksi dan kawasan hutan lindung".

Kemudian berdasarkan Pasal 33 Undang-Undang No. 5 Tahun 1990 tentang Konservasi Sumber Daya Alam Hayati dan Ekosistemnya:

(1) Setiap orang dilarang melakukan kegiatan yang dapat mengakibatkan perubahan terhadap keutuhan zona inti taman nasional.

(2) Perubahan terhadap keutuhan zona inti taman nasional sebagaimana dimaksud dalam ayat (1) meliputi mengurangi, menghilangkan fungsi dan luas zona inti taman nasional, serta menambah jenis tumbuhan dan satwa lain yang tidak asli.

(3) Setiap orang dilarang melakukan kegiatan yang tidak sesuai dengan fungsi zona pemanfaatan dan zona lain dari taman nasional, taman hutan raya, dan taman wisata alam.

Selanjutnya diatur dalam Pasal 35 ayat (1) Peraturan Pemerintah No. 26 Tahun 2011 tentang Pengelolaan Kawasan Suaka Alam dan Kawasan Pelestarian Alam:

(1) Taman nasional dapat dimanfaatkan untuk kegiatan:

a. penelitian dan pengembangan ilmu pengetahuan;

b. pendidikan dan peningkatan kesadartahuan konservasi alam;

c. penyimpanan dan/atau penyerapan karbon, pemanfaatan air serta energi air, panas, dan angin serta wisata alam; 
d. pemanfaatan tumbuhan dan satwa liar;

e. pemanfaatan sumber plasma nutfah untuk penunjang budidaya;

f. pemanfaatan tradisional oleh masyarakat setempat.

Mengenai frasa kata 'panas' dalam penjelasan Pasal 35 ayat (1) huruf c disebutkan pemanfaatan energi yang dapat diperbaharui, dihasilkan dari jasa panas yang pemanfaatannya tidak dilakukan melalui penambangan merujuk pada pemanfaatan energi panas matahari untuk pembangkit listrik (solar cell). Disamping itu, berdasarkan Pasal 2 ayat (1) Peraturan Presiden Nomor 28 Tahun 2011 tentang Penggunaan Kawasan Hutan Lindung: "Di dalam kawasan hutan lindung dapat dilakukan kegiatan penambangan dengan metode penambangan bawah tanah". Pasal 5 ayat (1) huruf b Peraturan Menteri Kehutanan Nomor P.16/MENHUT-II/2014 tentang Pedoman Pinjam Pakai Kawasan: "Dalam kawasan hutan lindung hanya dapat dilakukan penambangan dengan pola pertambangan bawah tanah dengan ketentuan dilarang mengakibatkan:

1. turunnya permukaan tanah;

2. berubahnya fungsi pokok kawasan hutan secara permanen; dan

3. terjadinya kerusakan akuiver air tanah."

Peraturan perundang-undangan yang telah dipaparkan di atas, dari segi muatannya membatasi pengusahaan panas bumi dalam kawasan hutan. Namun, di sisi pencapaian merujuk daftar proyek di atas dalam Nota Kesepahaman yaitu Pembangkit Listrik Tenaga Panas Bumi Cisolok Cisukarame Kabupaten Sukabumi dalam kawasan hutan koservasi Taman Nasional Gunung Salak di tahun 2016 mulai dilakukan ${ }^{9}$ tentunya keadaan tersebut bukanlah hal yang berdiri sendiri. Seiring berjalannya waktu serta perubahan untuk menunjang pasokan tenaga listrik nasional, mendorong Pemerintah pada tahun 2011 melalui Menteri Dalam Negeri Gamawan Fauzi mempersiapkan rancangan perubahan Undang-Undang

9 Reni Susanti, Kantongi Izin, Proyek Panas Bumi Cisolok-Sukarame Segera Terwujud, http://bisniskeuangan.kompas.com/read/2015/08/20/155000526/Kantongi.Izin.Proyek.Panas .Bumi.Cisolok-Sukarame.Segera.Terwujud, diakses 02 Oktober 2016. 
No. 32 Tahun 2004 tentang Pemerintahan Daerah. Selanjutnya memasuki tahap harmonisasi di Kementerian Hukum dan Hak Asasi Manusia memecah tiga bidang disertai pengaturan urusan dan kewenangan yang berbeda-beda yakni: (1) Rancangan Undang-Undang tentang Pemerintahan Daerah, Rancangan UndangUndang Pemilihan Kepala Daerah, dan Rancangan Undang-Undang tentang Desa (RUU). Khusus menyoroti RUU, Pemerintahan merumuskan 22 isu strategis. Dari beberapa isu strategis yang merujuk pada naskah akademik RUU Pemerintahan Daerah terdapat beberapa lingkup bersinggungan dengan pemanfaatan energi panas bumi dan ketenagalistrikan diantaranya sebagai berikut: (1) Pembagian urusan pemerintahan; (2) Partisipasi Masyarakat; (3) Kawasan Khusus berupa kawasan hutan lindung dan kawasan hutan konservasi10 tercantum dalam Program Legislasi Nasional (Prolegnas) prioritas 2012.

Sejalan dengan proses tersebut di tahun 2012, menteri Energi dan Sumber Daya Alam Mineral Jero Wacik turut mengajukan RUU tentang Panas Bumi, tercantum dalam Prolegnas prioritas tahun 2013 berdasarkan keputusan Dewan Perwakilan Rakyat Indonesia Nomor 04/DPRRI/II/2012/21013 tentang Program Legislasi Nasional pada nomor urut 65 yakni Rancangan Undang-undang tentang Perubahan atas Undang-Undang Nomor 27 Tahun 2003 tentang Panas Bumi sebagai RUU yang berasal dari Presiden dalam proses penyusunannya naskah akademik dan RUU Panas Bumi yang disiapkan oleh Pemerintah. ${ }^{11}$

Merujuk pada RUU Panas Bumi yang hendak mengubah enam hal yang selama ini dinilai menghambat implementasi pembangunan pembangkit listrik tenaga panas bumi di antaranya: (1) Pengaturan pengusahaan energi panas bumi di kawasan hutan konservasi; (2) Kewenangan pemerintah untuk eksplorasi dan eksploitasi yang diberikan penugasannya kepada kepada Badan Usaha Milik Negara dan badan usaha swasta untuk meningkatkan panas bumi; (3) Kewenangan Menteri untuk mencabut izin dan pembatalan izin yang diberikan

\footnotetext{
${ }^{10}$ Naskah Akademik Rancangan Undang-Undang tentang Pemerintah Daerah, Kementerian Dalam Negeri, 2011, hlm.54.

11 Risalah Rapat Paripurna Dewan Perwakilan Rakyat, 26 Agustus 2014, hlm.23.
} 
oleh Gubernur; (4) Ketentuan peralihan lebih tegas untuk jangka waktu pengelolaan panas bumi. ${ }^{12}$ Kemudian Undang-Undang Nomor 21 Tahun 2014 tentang Panas Bumi dan Undang-Undang No. 23 Tahun 2014 tentang Pemerintahan Daerah (UU Pemda 2014) disahkan dan diundangkan lebih awal dalam bulan yang sama yakni diantara tanggal 17 September 2014 dan 30 September 2014.

Berikut perbandingan antara Undang Nomor 32 Tahun 2004 tentang Pemerintahan Daerah (UU Pemda 2004) dan Undang-Undang No. 23 Tahun 2014 (UU 2014) dihubungkan dengan Undang- Undang-Undang Nomor 21 Tahun 2014 tentang Panas Bumi (UU Panas Bumi 2014) sebagai berikut:

1. Dalam UU Pemda 2004 asas otonomi dan tugas pembantuan secara tegas dirumuskan. Hal ini nampak berbeda dengan bagian pertimbangan UU Pemda 2014 yang tidak merumuskan secara tegas, namun justru dicantumkan pada bagian penjelasan. Hal ini menunjukan ketidakkonsistenan pengaturan hubungan kewenangan antara pusat dan daerah berdasarkan Pasal 18 ayat (2) dan ayat (5) Undang-Undang Dasar 1945 amandemen kedua yang menghendaki pemerintahan daerah menjalankan otonomi seluas-luasnya, kecuali urusan lain yang ditentukan sebagai urusan pemerintah pusat. Sedangkan Pasal 9 UU Pemda 2014 melakukan penyeragaman secara rinci kewenangan antara pusat, provinsi dan kabupaten/kota dalam urusan pemerintahan konkuren sehingga daerah otonom memiliki urusan yang sama dalam hal lintas sektor bidang kehutanan dan energi namun dengan kewenangan yang berbeda.

2. Mengenai perbedaan definisi desentralisasi, dekonsentrasi dan tugas pembantuan terlihat dalam table di bawah ini.

\begin{tabular}{lll}
\hline Definsi & UU Pemda 2004 & UU Pemda 2014 \\
\hline Desentralisasi & Penyerahan wewenang & Penyerahan Urusan \\
& pemerintahan oleh Pemerintah kepada & Pemerintahan oleh Pemerintah \\
& daerah otonom untuk & Pusat kepada daerah otonom \\
& mengatur dan mengurus urusan & berdasarkan Asas Otonomi. \\
\hline
\end{tabular}

${ }^{12}$ Naskah Akademik Rancangan Undang-Undang tentang Pemerintah Daerah, Kementerian Energi dan Sumber Daya Mineral, 2012, hlm. 9-10. 


\begin{tabular}{|c|c|c|}
\hline & $\begin{array}{l}\text { pemerintahan dalam Sistem Negara } \\
\text { Kesatuan Republik } \\
\text { Indonesia. }\end{array}$ & \\
\hline Dekonsentrasi & $\begin{array}{l}\text { Dekonsentrasi adalah } \\
\text { pelimpahan wewenang } \\
\text { pemerintahan oleh Pemerintah kepada } \\
\text { Gubernur sebagai wakil } \\
\text { pemerintah dan/atau kepada instansi } \\
\text { vertikal di wilayah tertentu. }\end{array}$ & 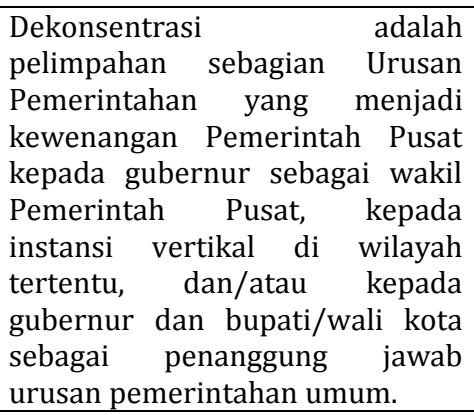 \\
\hline $\begin{array}{l}\text { Tugas } \\
\text { Pembantuan }\end{array}$ & $\begin{array}{l}\text { Tugas pembantuan adalah penugasan } \\
\text { dari Pemerintah kepada daerah dan/ } \\
\text { atau desa dari pemerintah provinsi } \\
\text { kepada kabupaten/kota dan/atau desa } \\
\text { serta dari pemerintah kabupaten/kota } \\
\text { kepada desa untuk melaksanakan } \\
\text { tugas tertentu. }\end{array}$ & $\begin{array}{l}\text { Tugas Pembantuan adalah } \\
\text { penugasan dari Pemerintah Pusat } \\
\text { kepada daerah otonom untuk } \\
\text { melaksanakan sebagian } \\
\text { Urusan Pemerintahan yang } \\
\text { menjadi kewenangan Pemerintah } \\
\text { Pusat atau dari Pemerintah } \\
\text { Daerah provinsi kepada Daerah } \\
\text { kabupaten/kota untuk } \\
\text { melaksanakan sebagian Urusan } \\
\text { Pemerintahan yang menjadi } \\
\text { kewenangan Daerah provinsi. }\end{array}$ \\
\hline
\end{tabular}

Dengan mencermati frasa 'urusan pemerintahan' pada tabel di atas, nampak terjadi perubahan mendasar dalam UU Pemda 2004 yang diatur dalam BAB I, KETENTUAN UMUM dan Pasal 1 yaitu dalam butir-butir berikut ini:

2. Pemerintahan daerah adalah penyelenggaraan 'urusan pemerintahan' oleh pemerintah daerah dan DPRD menurut asas otonomi dan tugas pembantuan dengan prinsip otonomi seluas-luasnya dalam sistem dan prinsip Negara Kesatuan Republik Indonesia sebagaimana dimaksud dalam Undang-Undang Dasar Negara Republik Indonesia Tahun 1945.

5. Otonomi daerah adalah hak, wewenang, dan kewajiban daerah otonom untuk mengatur dan mengurus sendiri 'urusan pemerintahan' dan kepentingan masyarakat setempat sesuai dengan peraturan perundang-undangan.

6. Daerah otonom, selanjutnya disebut daerah, adalah kesatuan masyarakat hukum yang mempunyai batas-batas wilayah yang 
berwenang mengatur dan mengurus 'urusan pemerintahan' dan kepentingan masyarakat setempat menurut prakarsa sendiri berdasarkan aspirasi masyarakat dalam sistem Negara Kesatuan Republik Indonesia.

Selanjutnya beberapa butir tersebut ditegaskan kembali dalam Bab III tentang Pembagian Urusan Pemerintahan Pasal 10 ayat (2) Undang-Undang No. 32 Tahun 2004:

(1) Pemerintahan daerah menyelenggarakan urusan pemerintahan yang menjadi kewenangannya, kecuali 'urusan pemerintahan' yang oleh Undang-Undang ini ditentukan menjadi urusan Pemerintah.

(2) Dalam menyelenggarakan urusan pemerintahan yang menjadi kewenangan daerah sebagaimana dimaksud pada ayat (1), pemerintahan daerah menjalankan otonomi seluas-luasnya untuk mengatur dan mengurus sendiri urusan pemerintahan berdasarkan asas otonomi dan tugas pembantuan.

Sedangkan UU Pemda 2014 memberikan nomenklatur urusan pemerintahan pada Bab 1 ketentuan umum angka:

5. Urusan Pemerintahan adalah kekuasaan pemerintahan yang menjadi kewenangan Presiden yang pelaksanaannya dilakukan oleh kementerian negara dan penyelenggara Pemerintahan Daerah untuk melindungi, melayani, memberdayakan, dan menyejahterakan masyarakat.

Kemudian ditegaskan kembali dalam Pasal 5 Bab III tentang Kekuasaan Pemerintahan:

(1) Presiden Republik Indonesia memegang kekuasaan pemerintahan sesuai dengan Undang-Undang Dasar Negara Republik Indonesia Tahun 1945.

(2) Kekuasaan Pemerintahan sebagaimana dimaksud pada ayat (1) diuraikan dalam berbagai Urusan Pemerintahan. 
(3) Dalam menyelenggarakan Urusan Pemerintahan sebagaimana dimaksud pada ayat (2), Presiden dibantu oleh menteri yang menyelenggarakan Urusan Pemerintahan tertentu.

(4) Penyelenggaraan Urusan Pemerintahan sebagaimana dimaksud pada ayat (2) di Daerah dilaksanakan berdasarkan asas Desentralisasi, Dekonsentrasi, dan Tugas Pembantuan.

Dari kutipan beberapa pasal di atas, terlihat adanya perubahan subyek hukum penyelenggara urusan pemerintahan daerah yaitu UU Pemda 2004 meletakkannya pada Pemerintah Daerah sementara UU Pemda 2014 pada Pemerintah Pusat. Di samping itu terkait pembagian urusan pemerintahan pilihan lintas sektor bidang kehutanan, energi dan sumber daya alam dalam lingkup urusan pemerintahan konkuren sebagaimana tercantum pada Pasal 14 yang merupakan bagian yang tidak terpisahkan dari UU Pemda 2014 dalam lampiran BB mengenai bidang kehutanan sub urusan konservasi sumber daya alam hayati dan ekosistemnya serta lampiran CC sektor energi dan sumber daya alam sub energi terbarukan seperti dijelaskan dalam Pasal 14 sebagai berikut:

(1) Penyelenggaraan Urusan Pemerintahan bidang kehutanan, kelautan, serta energi dan sumber daya mineral dibagi antara Pemerintah Pusat dan Daerah Provinsi.

(2) Urusan Pemerintahan bidang kehutanan sebagaimana dimaksud pada ayat (1) yang berkaitan dengan pengelolaan taman hutan raya kabupaten/kota menjadi kewenangan Daerah Kabupaten/Kota.

(3) Urusan Pemerintahan bidang energi dan sumber daya mineral sebagaimana dimaksud pada ayat (1) yang berkaitan dengan pengelolaan minyak dan gas bumi menjadi kewenangan Pemerintah Pusat.

\begin{tabular}{|c|c|}
\hline $\begin{array}{l}\text { Lampiran BB Pembagian Urusan } \\
\text { Pemerintahan Bidang Kehutanan }\end{array}$ & $\begin{array}{l}\text { Lampiran CC Pembagian Urusan } \\
\text { Pemerintahan Bidang Energi dan } \\
\text { Sumber Daya Mineral }\end{array}$ \\
\hline 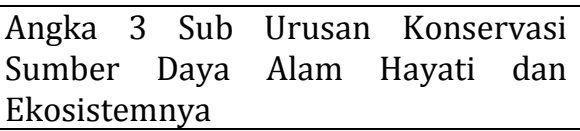 & Angka 4 Sub Energi Baru Terbarukan \\
\hline $\begin{array}{l}\text { Pemerintah Pusat berwenang } \\
\text { - } \quad \text { Mengelola kawasan suaka alam }\end{array}$ & $\begin{array}{l}\text { Pemerintah Pusat berwenang } \\
\text { - Menetapkan Wilayah Kerja }\end{array}$ \\
\hline
\end{tabular}




\begin{tabular}{|c|c|}
\hline $\begin{array}{l}\text { dan kawasan pelestarian alam } \\
\text { Pemerintah Provinsi berwenang } \\
\text { - Mengelola dan melaksanakan } \\
\text { pemanfaatan hutan di kawasan } \\
\text { hutan dan hutan lindung } \\
\text { Pemerintah Kabupaten/Kota } \\
\text { berwenang } \\
\text { - Mengelola taman hutan raya. }\end{array}$ & $\begin{array}{l}\text { Bumi. } \\
\text { - Melakukan pelelangan Wilayah Kerja } \\
\text { Panas Bumi. } \\
\text { - Menerbitkan izin pemanfaatan } \\
\text { langsung panas bumi lintas daerah } \\
\text { provinsi } \\
\text { - Menerbitkan Izin panas bumi untuk } \\
\text { pemanfaatan tidak langsung, } \\
\text { Pemerintah Provinsi berwenang } \\
\text { - Penerbitan izin pemanfaatan langsung } \\
\text { panas bumi lintas daerah } \\
\text { kabupaten/kota dalam } 1 \text { (satu daerah) } \\
\text { provinsi. } \\
\text { Pemerintah Kabupaten/Kota berwenang } \\
\text { - Penerbitan izin pemanfaatan langsung } \\
\text { panas bumi dalam daerah manfaatan } \\
\text { WKP panas bumi secara langsung dan } \\
\text { tidak langsung }\end{array}$ \\
\hline
\end{tabular}

Tabel: Pembagian urusan pemerintahan pilihan lintas sektor berdasarkan UndangUndang No. 23 Tahun 2014 tentang Pemerintahan Daerah

Mencermati rumusan Pasal 14 UU Pemda 2014 dengan lampiran di atas menyiratkan pengaturan urusan bidang kehutanan sub urusan konservasi sumber daya alam hayati dan ekosistemnya, energi dan sumber daya mineral sub energi baru terbarukan dibagi menjadi urusan Pemerintah Pusat dan Pemerintah Provinsi namun dibatasi secara administrasi dalam lingkup perizinan sebagaimana termuat dalam UU Panas Bumi 2014 sebagai berikut:

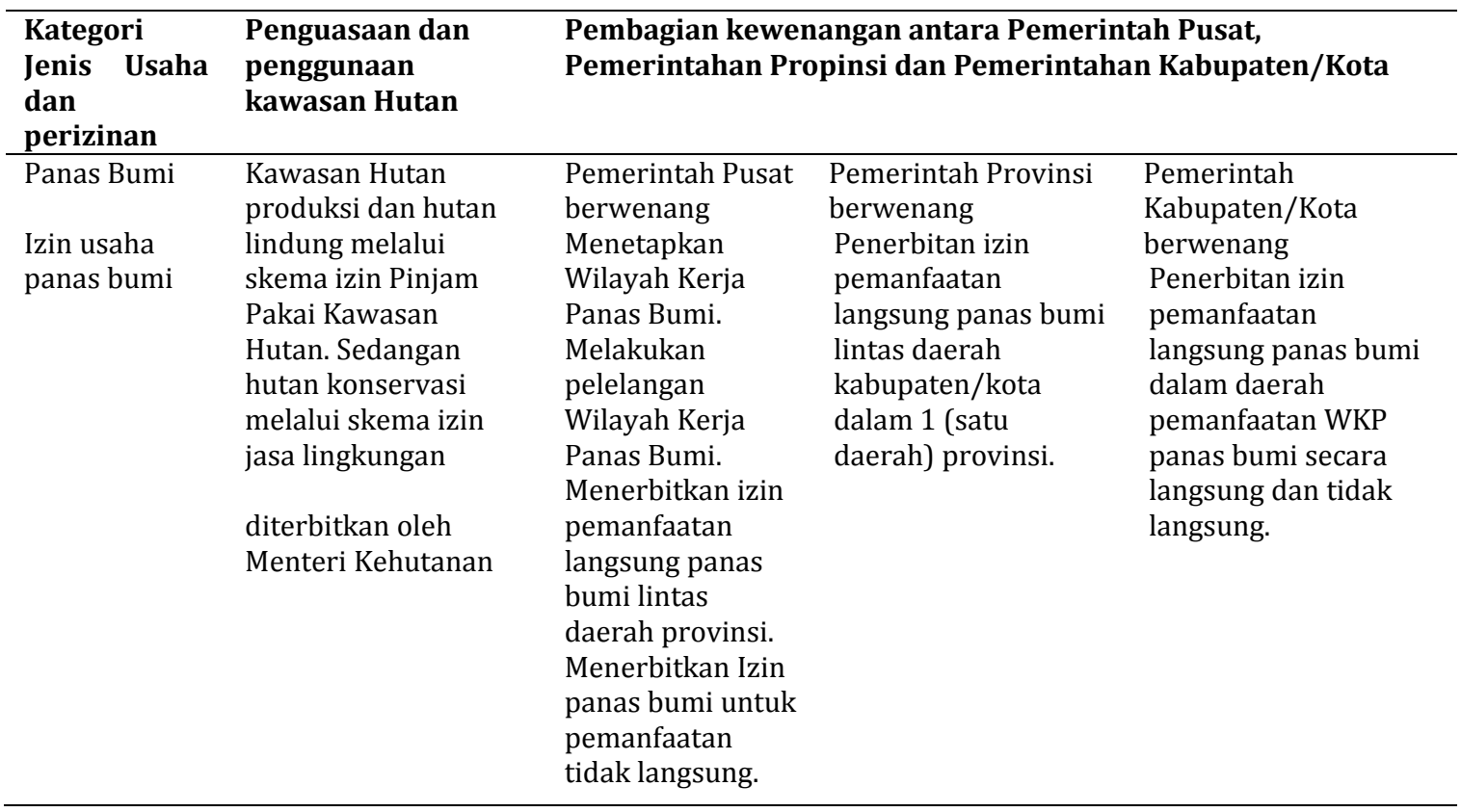


BAB VII

PENGGUNAAN LAHAN

Pasal 42

(1) Dalam hal akan menggunakan bidang-bidang tanah negara, hak atas tanah, tanah ulayat, dan/atau Kawasan Hutan di dalam Wilayah Kerja, pemegang Izin Pemanfaatan Langsung atau pemegang Izin Panas Bumi harus terlebih dahulu melakukan penyelesaian penggunaan lahan dengan pemakai tanah di atas tanah negara atau pemegang hak atau izin di bidang kehutanan sesuai dengan ketentuan peraturan perundangundangan.

\title{
Keseluruhan penjelasan di atas menunjukkan kecenderungan gejala
}

\section{resentralisasi terkait pengusahaan panas bumi ditinjau dari berapa prinsip} sebagaimana tertuang dalam penjelasan Pasal 13 ayat (1) UU Pemda 2014 sebagai

\author{
berikut: 13
}

\begin{tabular}{|c|c|c|}
\hline Prinsip & Definisi & Penjelasan \\
\hline Akuntabilitas & $\begin{array}{l}\text { Penanggungjawab penyelenggaraan } \\
\text { suatu Urusan Pemerintahan ditentukan } \\
\text { berdasarkan kedekatannya dengan luas, } \\
\text { besaran, dan jangkauan dampak yang } \\
\text { ditimbulkan oleh penyelenggaraan suatu } \\
\text { Urusan Pemerintahan }\end{array}$ & $\begin{array}{l}\text { Pengusahaan panas bumi untuk } \\
\text { pemanfaatan tidak langsung } \\
\text { diserahkan kepada pemerintah pusat } \\
\text { dalam menetapkan wilayah kerja } \\
\text { panas bumi dapat meminalisir potensi } \\
\text { konflik penambahan luas wilayah } \\
\text { kerja panas bumi yang tidak } \\
\text { memperhatikan batas-batas } \\
\text { administrasi. }\end{array}$ \\
\hline Efisiensi & $\begin{array}{l}\text { Penyelenggara suatu Urusan } \\
\text { Pemerintahan ditentukan berdasarkan } \\
\text { perbandingan tingkat daya guna yang } \\
\text { paling tinggi yang dapat } \\
\text { diperoleh. }\end{array}$ & $\begin{array}{l}\text { Pengusahaan panas bumi untuk } \\
\text { pemanfaatan tidak langsung } \\
\text { diserahkan kepada pemerintah pusat } \\
\text { mendorong harga listrik yang } \\
\text { dihasilkan dari panas bumi lebih } \\
\text { kompetitif dan lebih andal sehingga } \\
\text { menguntungkan ekonomi secara } \\
\text { nasional }\end{array}$ \\
\hline Eksternalitas & $\begin{array}{l}\text { Penyelenggara suatu Urusan } \\
\text { Pemerintahan ditentukan berdasarkan } \\
\text { luas, besaran, dan jangkauan dampak } \\
\text { yang timbul akibat penyelenggaraan } \\
\text { suatu Urusan Pemerintahan }\end{array}$ & $\begin{array}{l}\text { Pengusahaan panas bumi untuk } \\
\text { pemanfaatan tidak langsung } \\
\text { diserahkan kepada pemerintah pusat } \\
\text { karena lebih berdampak nasional atau } \\
\text { meluas secara ekonomi dan } \\
\text { digunakan secara nasional. }\end{array}$ \\
\hline $\begin{array}{l}\text { Kepentingan } \\
\text { Strategis }\end{array}$ & $\begin{array}{l}\text { Penyelenggara suatu Urusan } \\
\text { Pemerintahan ditentukan berdasarkan } \\
\text { pertimbangan dalam rangka menjaga } \\
\text { keutuhan dan kesatuan bangsa, menjaga } \\
\text { kedaulatan Negara, implementasi } \\
\text { hubungan luar negeri, pencapaian } \\
\text { program strategis nasional dan } \\
\text { pertimbangan lain yang diatur dalam } \\
\text { ketentuan peraturan perundang- } \\
\text { undangan }\end{array}$ & $\begin{array}{l}\text { Pengusahaan panas bumi untuk } \\
\text { pemanfaatan tidak langsung } \\
\text { diserahkan kepada pemerintah pusat } \\
\text { atau untuk pembangkitan tenaga } \\
\text { listrik bersifat sangat strategis dalam } \\
\text { menunjang ketahanan energi nasional } \\
\text { karena listrik yang dihasilkan dari } \\
\text { pembangkit listrik tenaga panas bumi } \\
\text { dapat dimanfaatkan lintas batas } \\
\text { administratif. }\end{array}$ \\
\hline
\end{tabular}

13 Mahkamah Konstitusi, Risalah Sidang Perkara Nomor 11/PUU/-XIV Perihal Pengujian UndangUndang No. 21 Tahun 2014 tentang Panas Bumi dan Undang-Undang No. 23 Tahun 2014 tentang Pemerintahan Daerah, 11 Mei 2016. 


\section{Penutup}

Mengenai urusan pemerintahan bidang energi dan sumber daya mineral energi sub energi baru terbarukan tidak termasuk dalam urusan pemerintahan absolut, dengan demikian Pemerintah Pusat menarik sebagian urusan mengenai pemanfaatan tidak langsung untuk keperluan tenaga listrik dan membatasi dalam lingkup pemanfaatan langsung untuk keperluan non tenaga listrik. Hal ini belum mencerminkan kehendak antar susunan pemerintahan sebagaimana termuat dalam Pasal 18 ayat (2) dan ayat (5) Undang-Undang Dasar 1945.

\section{Daftar Pustaka}

\section{Risalah}

Risalah Rapat Paripurna Dewan Perwakilan Rakyat, 26 Agustus 2014, Mahkamah Konstitusi, Risalah Sidang Perkara Nomor 11/PUU/-XIV Perihal Pengujian Undang-Undang 21 Tahun 2014 tentang Panas Bumi dan Undang-Undang 23 Tahun 2014 tentang Pemerintahan Daerah, 11 Mei 2016.

\section{Internet}

Tanpa Nama, Tanpa Pertumbuhan Pembangkit, 2018 Pulau Jawa Krisis Listrik, http://www.esdm.go.id/berita/39-listrik/6745-tanpa-pertumbuhanpembangkit-2018-pulau-jawa-krisis-listrik.html

Tanpa Nama, Pemerintah Dorong Swasta Kembangkan Listrik Perdesaan, http://www.djk.esdm.go.id/index.php/detail-berita?ide $=4210$.

Tanpa Nama, Industri Kelistrikan Indonesia, http://www.datacon.co.id/Listrik2011Industri.html, di akses 26 Maret 2015.

Gustidha Budiartie, Pendapatan Dari Hutan Ditargetkan Naik Pada 2011, https://m.tempo.co/read/news/2010/12/23/090301127/pendapatandari-hutan-ditargetkan-naik-pada-2011.

Administrator, Kronologis Perkembangan Wilayah Kerja Panas Bumi Gunung Ciremai, $\quad$ http://www.esdm.go.id/berita/323-energi-baru-danterbarukan/6747-kronologis-perkembangan-wilayah-kerja-panas-bumigunung-ciremai.html.

Sucipto, Pemerintah Ultimatum 12 Proyek Panas Bumi Mangkrak, http://m.wartaekonomi.co.id/berita10221/pemerintah-ultimatum-12proyek-panas-bumi-mangkrak.html.

Reni Susanti, Kantongi Izin, Proyek Panas Bumi Cisolok-Sukarame Segera Terwujud, 
http://bisniskeuangan.kompas.com/read/2015/08/20/155000526/Kanto ngi.Izin.Proyek.Panas.Bumi.Cisolok-Sukarame.Segera.Terwujud.

\section{Siaran Pers}

Siaran Pers Gerakan Massa Pejuang Untuk Rakyat, 07 Mei 2014. 